\title{
Pengukuran Dosis Radiasi dan Estimasi Efek Biologis yang Diterima Pasien Radiografi Gigi Anak Menggunakan TLD-100 pada Titik Pengukuran Mata dan Timus
}

\author{
Nurhayati $^{1^{*}}$, Dian Milvita ${ }^{1}$, Helfi Yanti ${ }^{2}$, Dyah Dwi Kusumawati \\ ${ }^{1}$ Jurusan Fisika Universitas Andalas \\ ${ }^{2}$ PTKMR BATAN jakarta \\ *yati290193@gmail.com
}

\begin{abstract}
ABSTRAK
Penelitian tentang pengukuran dosis radiasi yang diterima pasien radiografi gigi anak pada titik pengukuran mata dan timus telah dilakukan pada salah satu rumah sakit di kota Padang menggunakan TLD-100. Penelitian ini bertujuan mengukur dosis radiasi yang diterima pasien anak dan estimasi efek biologis yang timbul akibat paparan radiasi. Pengambilan data dilakukan dengan pengukuran dosis radiasi pada 15 orang pasien anak usia 1-15 tahun. Pengukuran dosis radiasi dilakukan saat penyinaran intraoral, dengan teknik yang sama dalam waktu yang berbeda. Hasil pengukuran menunjukkan dosis radiasi ratarata yang diterima pasien usia 1-5 tahun sebesar 0,031 mGy, pasien usia 5-10 tahun sebesar 0,063 mGy dan pasien usia 10-15 tahun sebesar 0,078 mGy. Mata menerima dosis radiasi rata-rata sebesar 0,074 $\mathrm{mGy}$ dan timus menerima dosis radiasi rata-rata sebesar 0,034 mGy. Berdasarkan pengukuran yang telah dilakukan dapat diperkirakan semua pasien akan menerima efek stokastik.

Kata kunci: dosis radiasi, mata, radiografi gigi, TLD-100, timus,
\end{abstract}

\section{ABSTRACT}

Research about measurement of radiation dose received by eyes and tymus of children patient during dental radiography at one hospital in Padang using TLD-100 has been done. This research aims are to measure radiation dose received by children and to estimate their biological effect. Data of radiation dose was measured from 15 patients with age range 1-15 years. Radiation dose measurements were done while intraoral radiation with the same technique with different of times. Results show that the average of radiation dose which is received by patient with age of $1-5$ years is $0.031 \mathrm{mGy}$, of 5-10 years is 0.063 $m G y$ and, of age 10-15 years is $0.078 \mathrm{mGy}$. The eyes received the average radiation dose about 0.074 $m G y$ and thymus about $0.034 \mathrm{mGy}$. Based on the measurement which has been done it can be estimated that all patients receive stochastic effect.

Keywords: dental radiography, eyes, radiation dose, thymus, TLD-100

\section{PENDAHULUAN}

Radiografi gigi merupakan proses mendiagnosis kelainan yang diderita pasien gigi dengan memanfaatkan sinar-X. Namun, ada organ-organ tubuh lain yang mungkin terkena paparan radiasi pada saat pengambilan foto gigi seperti mata, timus dan organ lainnya. Penerimaan dosis radiasi oleh organ-organ tersebut sebetulnya tidak diinginkan karena selain memberikan manfaat, sinar-X juga dapat menimbulkan bahaya. Sinar-X mampu mengionisasi molekul-molekul jaringan tubuh yang dilewatinya sehingga dapat menimbulkan efek biologis yang membahayakan pasien.

Pasien yang menjalani pemeriksaan radiodiagnostik terdiri dari berbagai usia mulai dari bayi sampai dewasa. Usia 0 sampai 15 tahun dikategorikan sebagai usia anak. Terdapat perbedaan fisik fisiologis maupun psikologis antara anak dan orang dewasa. Fungsi organ-organ tubuh anak belum matang. Demikian pula dengan fungsi pertahanan yang belum sempurna serta sel-sel tersebut masih dalam proses pertumbuhan sehingga sangat sensitif terhadap radiasi. Apabila sel-sel tersebut terpapar radiasi maka akan mudah rusak sehingga mempengaruhi pertumbuhan selanjutnya.

Pengukuran dosis radiasi yang diterima oleh pasien radiografi gigi anak menggunakan TLD-100 pernah dilakukan pada salah satu rumah sakit di kota Padang oleh Raudhah (2008). Penelitian ini dilakukan pada pasien radiografi gigi anak teknik intraoral dan pasien radiografi gigi anak teknik ekstraoral. Hasil penelitian menunjukkan bahwa tiroid menerima dosis radiasi yang lebih besar dari pada timus dengan hasil $0,0472 \mathrm{mSv}$ pada teknik intraoral dan 0,2179 $\mathrm{mSv}$ pada teknik ekstraoral. Penelitian tersebut melatarbelakangi penelitian yang dilakukan pada 166 
salah satu rumah sakit di kota Padang. Titik pengukuran diletakkan di organ mata dan timus yang merupakan organ kritis terdekat dari target penyinaran. Organ mata dan timus memiliki fungsi penting dalam pertumbuhan anak, dimana organ mata berfungsi untuk indra penglihatan dan timus sebagai pembantu pembentukan sel kekebalan tubuh. Penelitian ini perlu dilakukan karena pasien anak masih dalam masa pertumbuhan yang sangat sensitif terhadap paparan radiasi, sehingga perlu diketahui berapa besar dosis yang diterima pasien untuk mengantisipasi efek radiasi yang ditimbulkan dalam mengupayakan proteksi radiasi.

\section{METODE}

Pada penelitian ini dilakukan pengukuran dosis radiasi yang diterima organ mata dan timus pada pasien radiografi gigi anak dengan cara penomoran TLD-100 untuk masing-masing organ yang akan diukur bertujuan agar data yang didapatkan tidak tertukar ditunjukkan pada Gambar 1. TLD-100 yang telah diberi nomor ditempelkan pada organ yang akan diukur menggunakan selotip ditunjukkan pada Gambar 2. Selanjutnya dilakukan pemeriksaan radiografi dan pegukuran dosis radiasi yang diterima oleh pasien anak. Pemeriksaan radiografi gigi anak ditunjukkan pada Gambar 3.

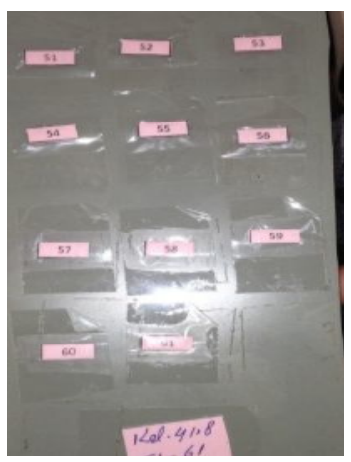

Gambar 1 Penomoran TLD-100

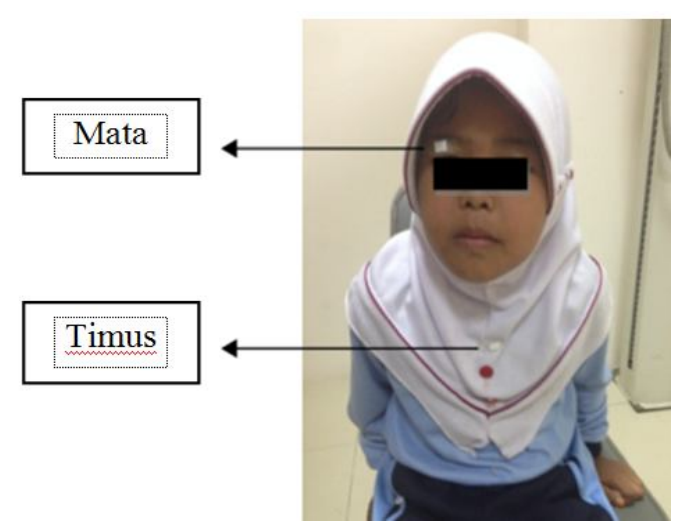

Gambar 2 Posisi TLD-100 pada organ pasien radiografi gigi anak

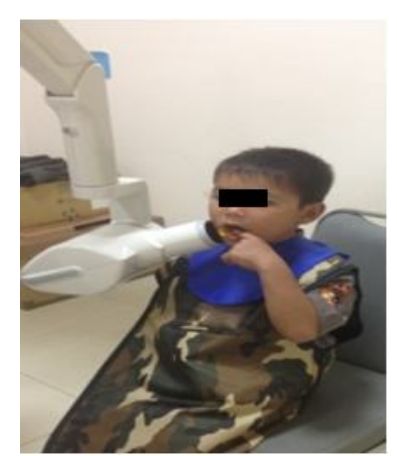

Gambar 3 Pemeriksaan radiografi gigi anak 
Hasil pengukuran menggunakan TLD-100 dibaca menggunakan TLD reader yang dilakukan oleh pihak PTKMR BATAN. Hasil pembacaan TLD-100 yang dilakukan oleh pihak PTKMR BATAN diperoleh nilai dosis radiasi yang diterima oleh pasien dan diketahui efek biologis yang timbul akibat paparan radiasi.

\section{HASIL DAN DISKUSI}

\subsection{Hasil pengukuran dosis radiasi menggunakan TLD-100}

\subsubsection{Hasil pengukuran dosis radiasi yang diterima pasien usia 1-5 tahun}

Pengukuran dosis radiasi yang diterima oleh pasien radiografi gigi anak usia 1-5 tahun menggunakan TLD-100 dapat dilihat pada Gambar 4. Hasil pengukuran dosis radiasi rata-rata yang diterima oleh pasien radiografi gigi anak untuk usia 1-5 tahun berada pada rentang 0,009$0,055 \mathrm{mGy}$. Dosis radiasi tertinggi diterima oleh pasien Af sebesar 0,055 mGy, sedangkan dosis terendah diterima oleh pasien $\mathrm{Fj}$ sebesar 0,009 mGy.

Berdasarkan hasil pengukuran yang ditunjukkan pada Gambar 4 pasien usia 1-5 tahun menerima paparan radiasi yang berbeda-beda. Hal ini dipengaruhi oleh perbedaan jenis gigi yang menjadi target pencitraan . Semakin ke dalam posisi gigi maka focal spot pesawat dental berada di atas permukaan pipi yang tidak mengenai gigi secara langsung, sehingga untuk mendapatkan hasil pencitraan dibutuhkan waktu paparan yang lebih lama dibandingkan dengan penyinaran pada gigi seri. Hal ini menyebabkan pasien menerima paparan radiasi yang lebih banyak. Faktor lain juga disebabkan oleh ketebalan gigi yang berbeda dan menyebabkan dosis radiasi yang dibutuhkan dalam pencitraan juga berbeda-beda. Faktor waktu merupakan hal yang harus diperhitungkan saat pengunaan sumber radiasi. Hal ini sesuai dengan pendapat Ramadani (2010) radiasi yang diterima sebanding dengan lamanya sumber radiasi bekerja, semakin lama sumber radiasi bekerja maka radiasi yang dipancarkan semakin besar, demikian sebaliknya.

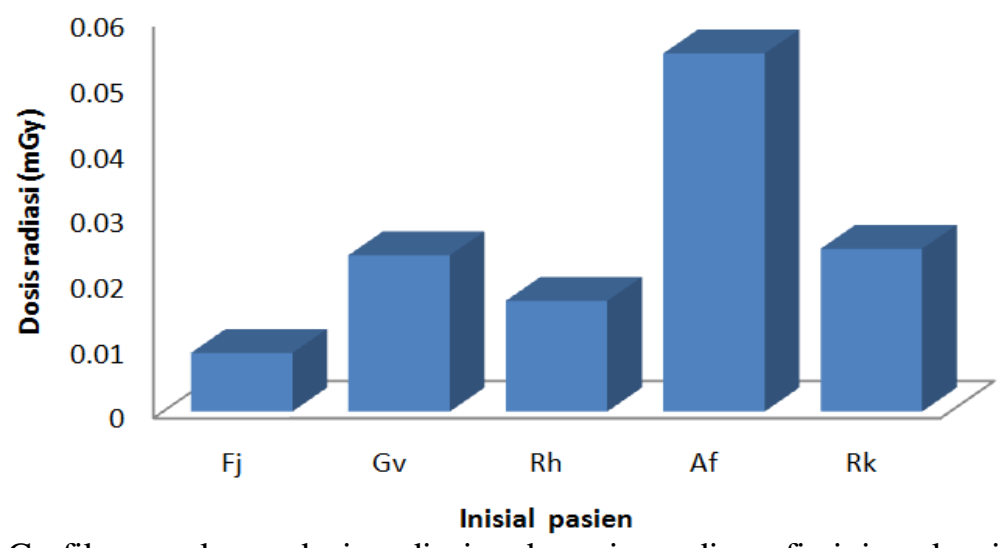

Gambar 4 Grafik pengukuran dosis radiasi pada pasien radiografi gigi anak usia 1-5 tahun menggunakan TLD-100.

\subsubsection{Hasil pengukuran dosis radiasi yang diterima pasien usia 5-10 tahun}

Hasil pengukuran dosis radiasi yang diterima oleh pasien radiografi gigi anak usia 5-10 tahun menggunakan TLD-100 ditunjukkan pada Gambar 5. Hasil pengukuran dosis radiasi ratarata yang diterima pasien anak usia 5-10 tahun berada pada rentang 0,024-0,100 mGy. Dosis radiasi tertinggi diterima oleh pasien $\mathrm{Dl}$ sebesar 0,100 $\mathrm{mGy}$, sedangkan dosis terendah diterima oleh pasien Ddk sebesar 0,024 mGy.

Berdasarkan Gambar 5 terlihat adanya variasi nilai dosis radiasi yang diterima pasien juga dipengaruhi oleh perbedaan jenis gigi yang akan menjadi target pencitraan. Pada pasien St dan Ay dilakukan pencitraan untuk jenis gigi yang sama, namun dosis radiasi yang diterima pasien berada pada rentang selisih $0,024 \mathrm{mGy}$. Pasien St menerima dosis radiasi rata-rata sebesar 0,044 mGy dan pasien Ay sebesar 0,068 mGy. Perbedaan dosis radiasi yang diterima pasien St dan Ay disebabkan karena pengaturan kontrol panel yang berbeda pada alat pesawat 
intraoral. Perbedaan jenis pengaturan kontrol panel yang digunakan disebabkan karena ketebalan objek pipi pasien St dan Ay berbeda.

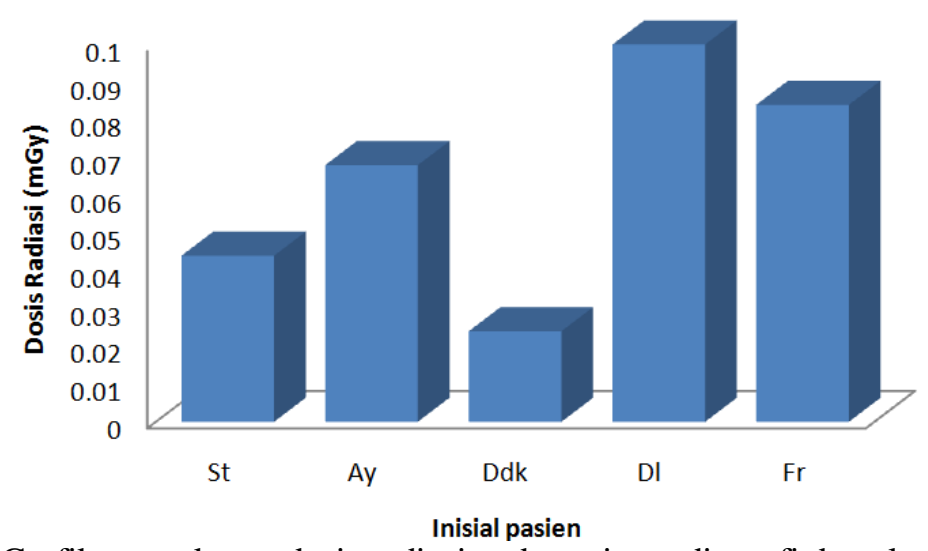

Gambar 5 Grafik pengukuran dosis radiasi pada pasien radiografi dental anak usia 5-10 tahun menggunakan TLD-100.

\subsubsection{Hasil pengukuran dosis radiasi yang diterima pasien usia 10-15 tahun}

Hasil pengukuran dosis radiasi yang diterima oleh pasien radiografi gigi anak usia 1015 tahun menggunakan TLD-100 ditunjukkan pada Gambar 6. Hasil pengukuran dosis radiasi rata-rata per pasien yang diterima anak usia 10-15 tahun berada pada rentang 0,027-0,147 mGy. Dosis radiasi tertinggi diterima oleh pasien $\mathrm{Zr}$ sebesar 0,147 mGy, sedangkan dosis terendah diterima oleh pasien Rn sebesar 0,027 mGy.

Adanya variasi nilai dosis radiasi yang diterima pasien juga dipengaruhi oleh perbedaan jenis gigi yang akan menjadi target pencitraan. Pasien $\mathrm{Sd}$ dan $\mathrm{Zr}$ menggunakan pengaturan kontrol panel jenis pasien remaja yang berbeda dari tiga pasien lainnya, karena kedua pasien ini memiliki postur tubuh yang lebih besar. Faktor massa mempengaruhi dosis radiasi yang diterima pasien karena adanya perpedaan faktor fisiologis, sehingga membutuhkan dosis radiasi yang lebih tinggi untuk mendapatkan kualitas pencitraan yang baik. Hal ini sesuai pendapat dengan Raudah (2008) bahwa semakin bertambahnya massa pasien maka dosis radiasi yang diberikan juga semakin besar.

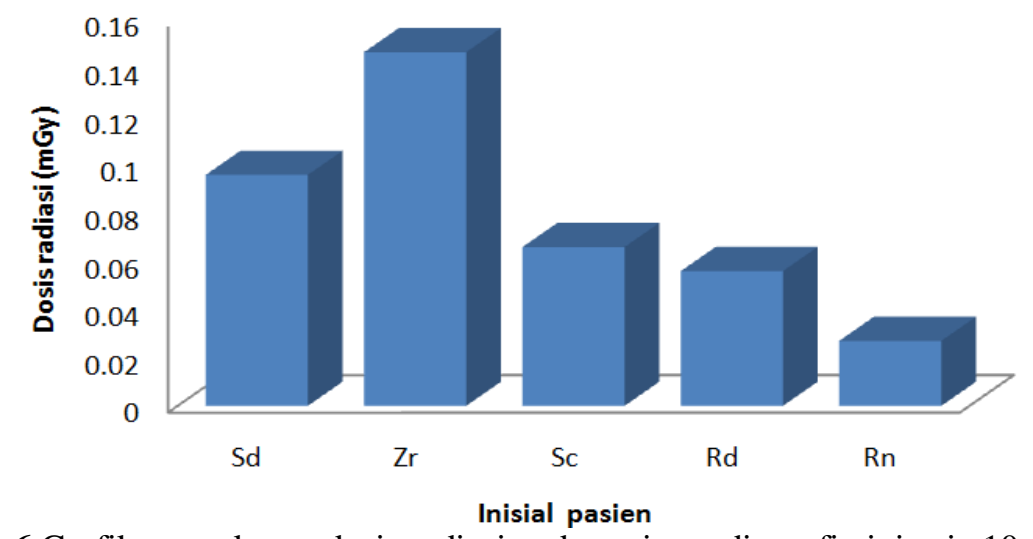

Gambar 6 Grafik pengukuran dosis radiasi pada pasien radiografi gigi usia 10-15 tahun menggunakan TLD-100

\subsubsection{Hasil pengukuran dosis radiasi yang diterima organ mata dan timus}

Hasil pengukuran dosis radiasi yang diterima oleh pasien radiografi gigi anak pada organ mata dan timus ditunjukkan pada Gambar 7. Besar dosis radiasi yang diterima oleh pasien untuk organ mata berada pada rentang $0,034-0,105 \mathrm{mGy}$ dan untuk organ timus berada pada rentang 0,018-0,051 mGy. Gambar 7 menunjukkan organ mata menerima dosis radiasi rata-rata yang jauh lebih besar dibandingkan organ timus. Hal ini disebabkan oleh perbedaan 
jarak antara kedua organ dengan sumber radiasi. Organ mata lebih dekat dengan sumber radiasi dibandingkan dengan organ timus, sehingga mata menerima paparan radiasi yang lebih banyak dibandingkan timus. Faktor lain juga disebabkan karena pengunaan alat proteksi radiasi berupa kacamata $\mathrm{Pb}$ yang tidak dipakai saat proses radiografi. Hal ini menyebabkan paparan radiasi yang berasal dari sumber radiasi langsung mengenai mata. Penggunaan baju apron pada timus mempengaruhi nilai dosis radiasi yang diterima pasien lebih rendah karena baju apron akan mengurangi nilai intensitas. Akhadi (2000) menyimpulkan bahwa intesitas radiasi setelah memasuki bahan penyerap lebih kecil dibandingkan intensitas semula.

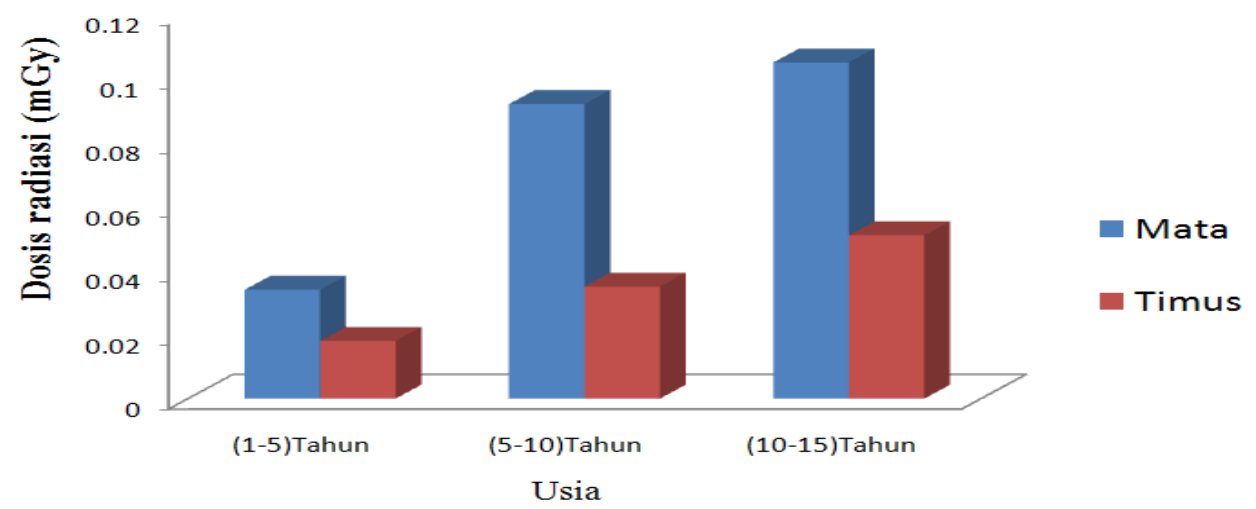

Gambar 7 Grafik pengukuran dosis radiasi pada organ mata dan timus menggunakan TLD-

100

\subsection{Estimasi efek biologis yang timbul akibat paparan radiasi pada pasien radiografi gigi anak}

Estimasi efek biologis yang timbul akibat paparan radiasi pada pasien radiografi gigi anak ditunjukkan pada Tabel 1. Berdasarkan Tabel 1 hasil pengukuran dosis efektif yang diterima pasien berkisar 0,004-0,073 $\mathrm{mSv}$, sehingga efek radiasi yang diperkirakan muncul adalah efek stokastik. Efek stokastik dapat berupa efek somatik maupun genetik. Menurut Akhadi (2000), efek radiasi yang terjadi pada pasien yang menerima radiasi untuk tujuan medis umumnya adalah efek somatik (kanker) dan efek genetik (cacat keturunan) yang akibatnya baru muncul setelah 10 sampai 35 tahun. Usia pasien tertinggi pada penelitian ini berada pada rentang 10-15 tahun, dimana pada kurun waktu 10 tahun kedepan merupakan usia produktif bagi pasien untuk menghasilkan keturunan, sehingga adanya kemungkinan mengalami efek genetik (cacat keturunan).

Tabel 1 Estimasi efek biologis yang timbul akibat paparan radiasi pada pasien radiografi dental anak

\begin{tabular}{|c|c|c|c|c|c|c|}
\hline \multirow{2}{*}{$\begin{array}{l}\text { Usia pasien } \\
\text { (Tahun) }\end{array}$} & \multirow[t]{2}{*}{ No } & \multirow[t]{2}{*}{$\begin{array}{l}\text { Inisial } \\
\text { pasien }\end{array}$} & \multicolumn{2}{|c|}{$\begin{array}{c}\text { Dosis efektif } \\
(\mathrm{mSv})\end{array}$} & \multirow{2}{*}{$\begin{array}{c}\text { Dosis efektif } \\
\text { rata-rata/ pasien } \\
(\mathrm{mSv})\end{array}$} & \multirow[t]{2}{*}{ Efek biologis } \\
\hline & & & Mata & Timus & & \\
\hline \multirow{5}{*}{$1-5$} & 1 & $\mathrm{Fj}$ & 0,0005 & 0,0004 & 0,0004 & Efek stokastik \\
\hline & 2 & $\mathrm{Gv}$ & 0,0013 & 0,0010 & 0,0012 & Efek stokastik \\
\hline & 3 & $\mathrm{Rh}$ & 0,0011 & 0,0005 & 0,0008 & Efek stokastik \\
\hline & 4 & Af & 0,0041 & 0,0013 & 0,0027 & Efek stokastik \\
\hline & 5 & $\mathrm{Rk}$ & 0,0013 & 0,0011 & 0,0012 & Efek stokastik \\
\hline \multirow{5}{*}{$5-10$} & 11 & $\mathrm{St}$ & 0,0028 & 0,0015 & 0,0022 & Efek stokastik \\
\hline & 12 & Ay & 0,0059 & 0,0008 & 0,0034 & Efek stokastik \\
\hline & 13 & Ddk & 0,0012 & 0,0117 & 0,0064 & Efek stokastik \\
\hline & 14 & Dl & 0,0057 & 0,0043 & 0,0050 & Efek stokastik \\
\hline & 15 & $\mathrm{Fr}$ & 0,0073 & 0,0010 & 0,0042 & Efek stokastik \\
\hline \multirow{5}{*}{$10-15$} & 21 & $\mathrm{Sd}$ & 0,0058 & 0,0037 & 0,0048 & Efek stokastik \\
\hline & 22 & $\mathrm{Zr}$ & 0,0114 & 0,0033 & 0,0073 & Efek stokastik \\
\hline & 23 & $\mathrm{Sc}$ & 0,0042 & 0,0024 & 0,0033 & Efek stokastik \\
\hline & 24 & $\mathrm{Rd}$ & 0,0029 & 0,0026 & 0,0028 & Efek stokastik \\
\hline & 25 & $\mathrm{Rn}$ & 0,0019 & 0,0007 & 0,0013 & Efek stokastik \\
\hline
\end{tabular}


Mata dan timus merupakan organ kritis yang terdekat dengan target penyinaran (gigi). Kedua organ tersebut memiliki fungsi yang sangat penting dalam masa pertumbuhan anak, sehingga paparan radiasi yang berlebihan akan berdampak terhadap fungsi kedua organ dalam masa pertumbuhan. Dampak paparan radiasi pada organ timus dapat mempengaruhi fungsi timus dalam memproduksi sel kekebalan tubuh dan pada organ mata dapat menyebabkan kerusakan pada lensa mata. Hal ini sesuai dengan pendapat Masdi, dkk. (2013) Kerusakan pada lensa mata diawali dengan terbentuknya titik-titik kekeruhan atau hilangnya sifat transparansi sel serabut lensa yang mulai dapat dideteksi setelah paparan radiasi $500 \mathrm{mGy}$.

\section{KESIMPULAN}

Dari penelitian ini dapat disimpulkan bahwa dosis radiasi rata-rata yang diterima pasien usia 1-5 tahun sebesar 0,031 mGy, pasien usia 5-10 tahun sebesar 0,063 mGy dan pasien usia 10-15 tahun sebesar 0,078 mGy. Mata menerima dosis radiasi rata-rata sebesar 0,074 mGy dan timus menerima dosis radiasi rata-rata sebesar $0,034 \mathrm{mGy}$, sehingga estimasi efek biologis yang ditimbulkan akibat paparan radiasi pada pasien radiografi gigi anak berupa efek stokastik.

\section{DAFTAR PUSTAKA}

Akhadi, M., Dasar-Dasar Proteksi Radiasi (PT. Rineka Cipta, Jakarta, 2000), 97-98

Masdi, Setiawati, E. dan Anam, C., Younger Physics Journal 1, 117-184 (2013).

Ramadani, "Compliance Test pada Pesawat Dental Panoramik Merek Orthopanthomograp OP 100 Type D-051S", Skripsi S1, Universitas Andalas, 2010.

Raudhah, U, "Distribusi Terimaan Dosis Radiasi pada Kegiatan Radiografi Dental Anak", Skripsi S1, Universitas Andalas, 2008. 